\title{
LOW COST MULTI-LAYER FABRICATION METHOD FOR SOLID OXIDE FUEL CELLS (SOFC)
}

\author{
Topical Report \\ Phase I. Economic Evaluation
}

For the Period: May 2000 to June 2000

Dr. Christopher E. Milliken, Materials Group Leader

Dr. Robert C. Ruhl, Vice President, Technology

Technology Management, Inc.

9718 Lake Shore Boulevard

Cleveland, Ohio 44108

May $16^{\text {th }}, 2001$

\section{Contract \# DE-AC26-0NT40707}

"This report was prepared as an account of work sponsored by an agency of the United States Government. Neither the United States Government nor any agency thereof, nor any of there employees, makes any warranty, expressed or implied, or assumes any legal liability or responsibility for the accuracy, completeness, or usefulness of any information, apparatus, product, or process disclosed, or represents that its use would not infringe privately owned rights. Reference herein to any specific commercial product, process, or service by trade name, trademark, manufacturer, or otherwise does not necessarily constitute or imply its endorsement, recommendation, or favoring by the United States Government or any agency thereof. The views and opinions of the authors expressed herein do not necessarily state or reflect those of the United States Government or any agency thereof." 


\begin{abstract}
Under this program, Technology Management, Inc, is evaluating the economic advantages of a multi-pass printing process on the costs of fabricating planar solid oxide fuel cell stacks. The technique, still unproven technically, uses a 'green-field' or build-up approach. Other more mature processes were considered to obtain some baseline assumptions. Based on this analysis, TMI has shown that multi-pass printing can offer substantial economic advantages over many existing fabrication processes and can reduce costs. By impacting overall production costs, the time is compressed to penetrate early low volume niche markets and more mature high-volume market applications.
\end{abstract}




\section{Table of Contents}

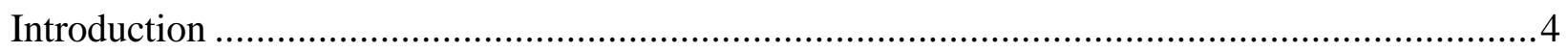

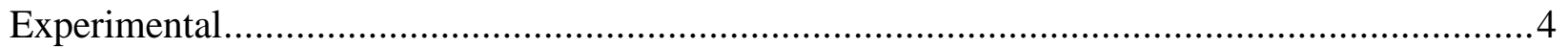

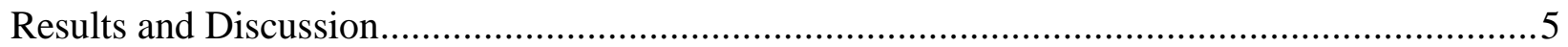

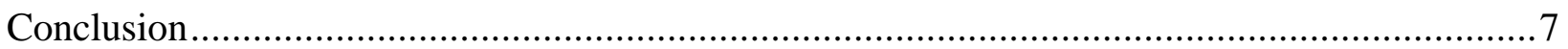

\section{List(s) of Graphical Materials}

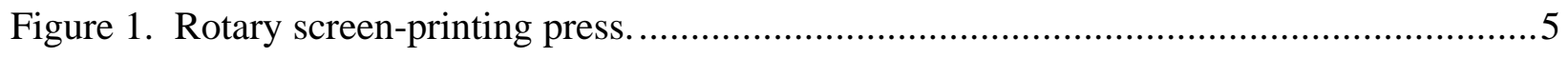

Figure 2. Economic Impact of Multi-pass fabrication on Stack Costs ................................6

Figure 3. Multi-pass Printing can Facilitate Niche Markets and Early Adopters. ....................6 


\section{Introduction}

Affordable per unit cost is a major factor influencing demand and early sales volume and the rate of technology adoption. Reduced per unit costs require increase production scale, however, capital investment often first requires 'proof of concept.' This creates a "chicken-and-egg" problem for early market business development. Solid Oxide Fuel Cell (SOFC) technology, being developed by a number of companies including Technology Management, Inc., now faces that challenge.

Anticipating this situation, Technology Management, Inc. (TMI) is considering alternate fabrication processes based on catalyzed ink-printing systems that could dramatically reduce the capital investment requirements dramatically. Although implementation of this concept would require a number of technical challenges, a meaningful financial evaluation was possible based on comparisons with existing products and applications. In 2000, with funding from the Department of Energy (NETL), TMI completed a preliminary evaluation of the impact of multipass printing on SOFC costs using internal models for comparison. Future topical reports will discuss binder selection and preliminary cell results.

\section{Experimental}

The preliminary cost analysis for multi-cell stacks was completed using a 'build up' approach of materials costs and expected yield factors. Expected capital cost and amortization, labor costs (including initial costs and benefits, escalation rates, etc.), and materials costs were considered. For materials costs, a survey of raw materials costs in bulk were available for most of the compounds used in the SOFC ${ }^{[1]}$. For example, the average price of electrolyte (yttria stabilized zirconia or YSZ) is dependent on purity. Presently, suppliers charge between $\$ 65$ and $\sim \$ 120 / \mathrm{kg}$ for high-grade $8 \mathrm{~mol} \%$ YSZ which is a factor of 2-3 times the cost of the weighted average of the raw materials. The average price of commercial grade monoclinic zirconia in bulk in 1999 was $\sim 23 / \mathrm{kg}$. The cost of yttrium oxide ranges from $\$ 22.00$ per kilogram for $99 \%$ purity to $\$ 85$ per kilogram for $99.99 \%$ purity. Even in large quantity, the combined cost is unlikely to be significantly less than the sum of the individual components. Relatively conservative targets were chosen for this analysis. Costs for mixed oxides (cathode materials in particular) were based on several discussions with vendors and their expectations of long term costs. This also included consideration of bulk-raw materials costs.

The capital equipment selected for the case study was a 10 station, commercially-available, rotary printer (see Figure 1). Each screen printing unit can produce a complete PEN (Positive electrode, Electrolyte, Negative electrode) cell. This particular unit has 10 stations, enough for two cell fabrication pathways / rotation (each cell would have two collector/manifolds and two seal steps). Assuming 2 shifts/day, 5 days/week, 50 weeks/year, one machine should be able to produce approximately one cell per minute or about 1,000,000 cells per year.

[1] 1999 U.S. Geological Survey 
Figure 1. Rotary screen-printing press.

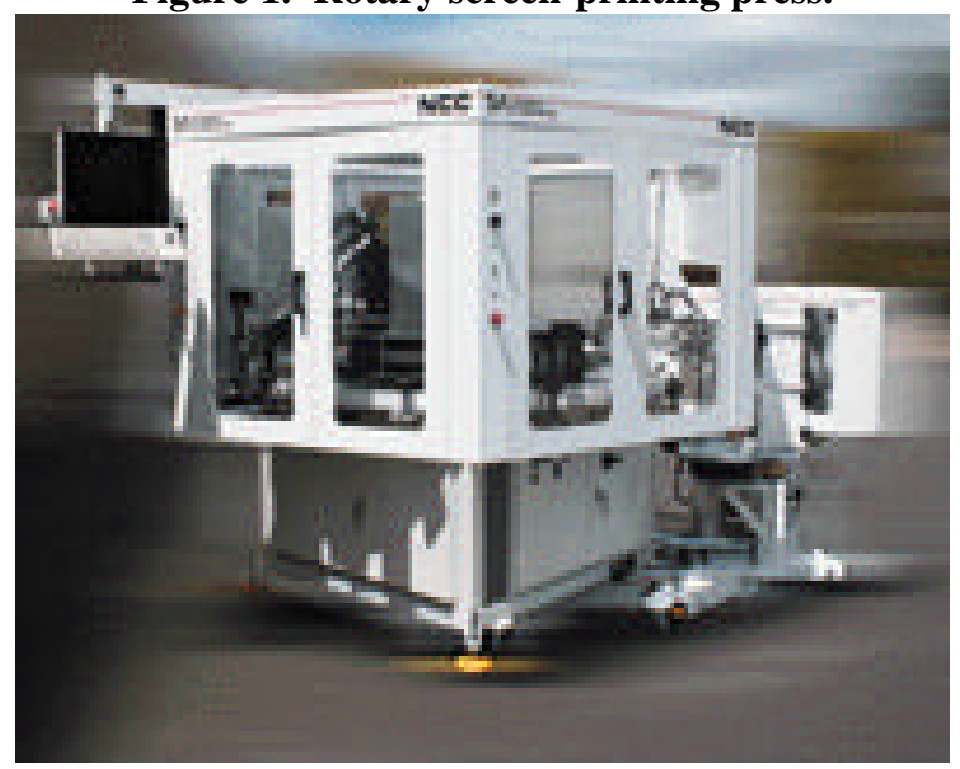

\section{Results and Discussion}

The results of the economic analysis are shown in figures 2 and 3. Figure 2 shows that final stack costs using a multi-pass process could be reduced by up to $40 \%$ in large volume compared to the base case analysis. The base case assumed individual components manufactured separately and assembled at the end. The largest improvements came from reduced materials costs because of reduce waste and reduce labor costs.

Figure 3 shows how benefits of the multi-pass fabrication process are realized earlier by reducing stack costs 'earlier' (i.e., at lower production quantities). This is particularly attractive for niche marketing strategies that do not support large volume demand.

Because specific markets for SOFCs are still undetermined and because materials of construction have not been established, any projections are speculative. Notwithstanding this, Technology Management, Inc. has applied its business experience to create a forecast. For virtually all projections, materials costs and labor content are the major cost components, even for high volume stack costs. Thus, the multi-pass printing approach is expected to be superior to most other fabrication strategies because the technique produces minimal waste and requires low labor. 
Figure 2. Economic Impact of Multi-pass fabrication on Stack Costs

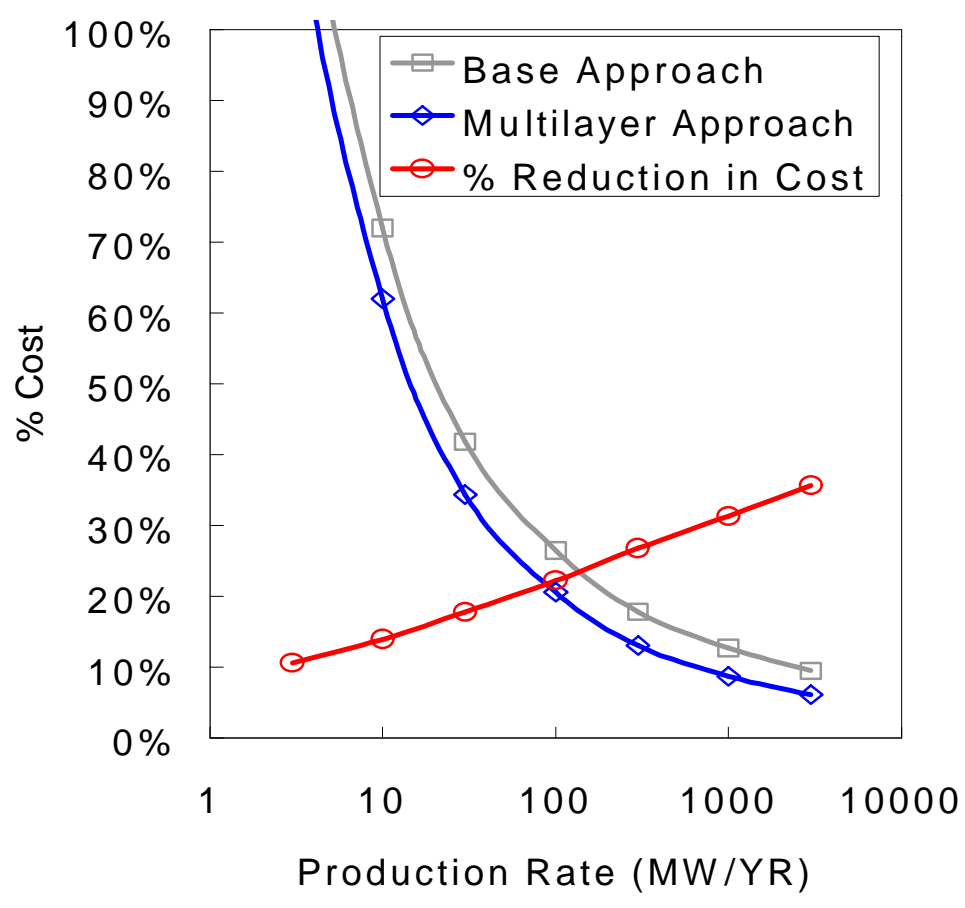

Figure 3. Multi-pass Printing can Facilitate Niche Markets and Early Adopters.

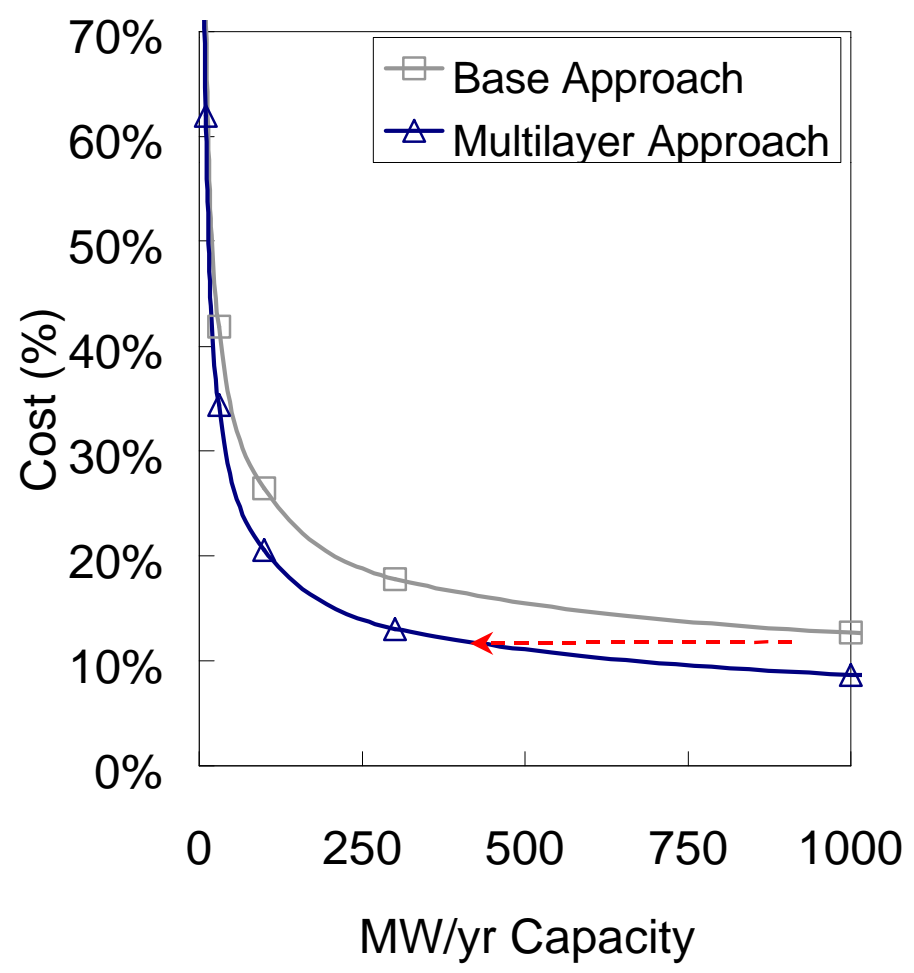




\section{Conclusion}

Technology Management, Inc. has determined that a multi-pass fabrication strategy can lead to reduced cost and therefore earlier penetration of both early adopter markets and long-term, highvolume markets. The challenges are substantial but not overwhelming. Future reports will consider other topical issues such as binder-to-SOFC materials interactions as well as curing rates and other fabrication challenges. The final proof of this fabrication approach will require actual cell tests with measured experimental performance correlated to fabrication parameters. 